УДК 612.461+004.62

DOI: http://dx.doi.org/10.11603/mie.1996-1960.2016.3.6759

\title{
HOW RELIABLE ARE CALIBRATORS FOR URINARY MELATONIN SULFATE?
}

\author{
G. P. Chuiko, O. V. Dvornyk, I. O. Shyian \\ Petro Mohyla Black Sea National University
}

\begin{abstract}
Melatonin is a versatile physiological agent that relating to the control of numerous physiologic processes owing to the multiplicity of sites of formation and the presence of melatonin receptors in various places of a human body. The melatonin metabolite 6-sulphatoxymelatonin (alias aMT6s or 6-SMT) infiltrates in urine. Therefore, there is a sense to find the sensitive and selective express-methods for the precise detection of melatonin metabolites in body fluids.

The calibrators are proper tools for the signal processing. In the present research work that is the set of few calibers with well-defined concentrations of analyte. Comparison of the measured response of actual sample with reactions of calibers permits to interpret the real signal. Such a response can be either the transmittance or the optical density of sample that are measured by a photometer. The calibration of dose-response relation has been described by logistic Hill's curve with four parameters. The photometric transmittances of analyzed solutions were considered as the response. This paper describes the evaluation and comparison of sets of Hill's parameters for aMT6s-calibrators of independent producers. Reliable calibrators could help to simplify the analysis of urinary melatonin-sulfate dose. Such express-analysis could be more accessible in addition. Hence, the problem of creation of reliable calibrators is still unsolved and challenging.
\end{abstract}

Key words: urinary melatonin-sulfate, dose-response relationship, Hill's equation, computer fitting, calibrators, photometry.

\section{НАСКІЛЬКИ НАДІЙНИМИ Є КАЛІБРАТОРИ ДЛЯ МЕЛАТОНІНУ СУЛЬФАТУ В СЕЧІ?}

\author{
Г. П. Чуйко, О. В. Дворник, І. О. Шиян \\ Чорноморський національний університет імені Петра Могили
}

\begin{abstract}
Мелатонін є універсальною фрізіологічною речовиною, яка синтезується в різних місцях людського тіла і допомагає здійснювати контроль над більшістю фрізіологічних процесів. Встановлено, що метаболіт мелатоніну 6-сульфратоксимелатонін (скорочено aMT6s або 6-SMT) виділяється з сечею. Таким чином, є сенс знайти чутливі і селективні експрес-методи для точного виявлення метаболітів мелатоніну в рідинах організму.

Часто калібратори являються належними інструментами для обробки сигналів. У даній дослідній роботі це є набір кількох калібраторів з чітко визначеними концентраціями аналіту. Порівняння виміряного відгуку фрактичного зразка з реакціями калібраторів дозволяє інтерпретувати реальний сигнал. Таким відгуком може бути або коефріцієнт пропускання, або оптична щільність зразка, що вимірюється за допомогою фотометра. Виявлення надійних калібраторів може суттєво спростити аналіз дози мелатоніну-сульфату в сечі. Такий експрес-аналіз може бути більш доступним.

Калібрування співвідношення доза-реакція була здійснено логістичною кривою Хілла з чотирма параметрами. Фотометричні коефіцієнти пропускання аналізованих розчинів розглядалися в якості вимірюваного відгуку. Метою представленої роботи була оцінка і порівняння наборів параметрів Хілла для аMT6s-калібраторів незалежних виробників. На жаль, наш результат демонструє значні і нез'ясовані розбіжності між ними. Отже, проблема створення надійних калібраторів сечового мелатоніну все ще не вирішена і актуальна.
\end{abstract}

Ключові слова: сечовий мелатонін-сульфат, крива доза-ефект, рівняння Хілла, калібратори, фотометрія.

\section{НАСКОЛЬКО ДОСТОВЕРНЫ КАЛИБРАТОРЫ ДЛЯ МЕЛАТОНИНА СУЛЬФАТА В МОЧЕ?}

\author{
Г. П. Чуйко, О. В. Дворник, И. А. Шиян \\ Черноморский национальный университет имени Петра Могилы
}

\begin{abstract}
Мелатонин является универсальным оризиологическим веществом, которое синтезируется в разных местах человеческого организма и помогает осуществлять контроль над большинством физиологических процессов. Установлено, что метаболит мелатонина 6-сульфатоксимелатонин (сокращенно aMT6s или 6-SMT) выделяется с мочой. Таким
\end{abstract}

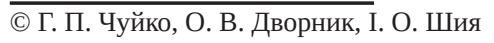


образом, есть смысл найти чувствительные и селективные экспресс-методы для точного выявления метаболитов мелатонина в жидкостях организма.

Часто калибраторы являются надежными инструментами для обработки сигналов. В данной исследовательской работе это набор нескольких калибраторов с четко определенными концентрациями аналита. Сравнение измеренного отклика фрактического образца с реакциями калибраторов позволяет интерпретировать реальный сигнал. Таким откликом может быть либо коэфффициент пропускания, или оптическая плотность образца, которая измеряется с помощью фротометра. Выявление надежных калибраторов может существенно упростить анализ дозы мелатонина-сульфата в моче. Такой экспресс-анализ может быть более доступным.

Калибровка отношения доза-реакция была описана логистической кривой Хилла с четырьмя параметрами. Фотометрические коэфффициенты пропускания анализируемых растворов рассматривались в качестве отклика. Целью представленной работы была оценка и сравнение наборов параметров Хилла для аMT6s-калибраторов независимых производителей. К сожалению, наш результат демонстрирует значительные и необъяснимые расхождения между ними. Итак, проблема создания надежных калибраторов мочевого мелатонина все еще не решена и актуальна.

Ключевые слова: мочевой мелатонин-сульфрат, кривая доза-эффрект, уравнение Хилла, калибраторы, фротометрия.

Introduction. Melatonin is a versatile physiological agent that relating to the control of numerous physiologic processes owing to the multiplicity of sites of formation and the presence of melatonin receptors in various places of a human body [4]. Existing data suggest that melatonin is affecting human physiology overall, including the sleep-wake cycle, via the body's internal clock [5]. It's established fact that melatonin is present in saliva or blood plasma, and the melatonin metabolite 6-sulphatoxymelatonin (alias aMT6s or 6 -SMT) infiltrates in urine $[4,5]$. Therefore, the search of sensitive and selective express-methods for the precise detection of melatonin metabolites in body fluids looks as worthy aim.

One of the most popular modern methods of melatonin detection in the urine is enzyme-linked immunosorbent assays (ELISA) [2, 7-9]. Such a more or less complicated biochemical test measures the presence and concentration of a macromolecule in a solution with high sensitivity. The package of reagents for urinary Melatonin-Sulfate analysis is quite expensive yet, and this test requires the special qualification of staff.

Often, the calibrators are proper tools for the signal processing. In our case, that is the set of few solutions (calibers) with well-defined concentrations of analyte. Comparison of the measured response of actual sample with reactions of calibers provides possible to interpret the real signal. Such a response can be either the transmittance or the optical density of sample [2, 6-9] that are measured by a photometer. It would certainly simplify the analysis of urinary melatonin-sulfate dose, if we had reliable calibrators. Such express-analysis could be more accessible in addition.

The calibration of dose-response relationship has been described most frequently by logistic Hill's curve with four parameters $[1,3]$. The goal of this paper is the computing and comparison of sets of Hill's parameters for aMT6s-calibrators of independent producers.

Materials and methods. Two different methods were used for preparation and testing of calibers with known dosage of aMT6s in human urine. The first of them is above mentioned enzyme-linked immunosorbent assays (ELISA) [2, 8-9]. Another is radioimmunoassay (RIA) that commonly recognized as extremely sensitive assay technique [6].

Here should be underlined that a number of authors are using the same set of calibers tested by ELISA within different laboratories [2, 3, 7, 8]. Other authors are using different sets of calibers that tested by different methods (ELISA and RIA) but within one laboratory [6, 9]. Therefore, all of them were dealing just with three different calibrators.

The dosage of aMT6s is within range (0-420) ng/ $\mathrm{mL}$. The calibers number of a calibrator is varied up 6 to 8 [2, 6-9].

Theory and calculations. The Hill's logistic equation looks so [1]:

$$
Y=a+\frac{b-a}{\left(1+(c / x)^{d}\right)}
$$

Here $\mathrm{Y}$ is the expected response at dosage $\mathrm{x}$. Parameter a is the minimum asymptote or the response when $\mathrm{x}->\infty$. Whereas $\mathrm{b}$ is the maximum asymptote or the stabilized response for a zero dosage $\mathrm{x}->\infty$. Parameter c defines the point of inflection in the dosage - response curve and is denoted by various terms (e. g. $\mathrm{EC}_{50}, \mathrm{ED}_{50}, \mathrm{LD}_{50}, \mathrm{IC}_{50}$ ). The last parameter $\mathrm{d}$ is the slope at the steepest part of the curve. This factor is also known as the Hill's slope [1]. The Fig. 1 demonstrates the Hill's logistic curve with descriptions of these parameters. 


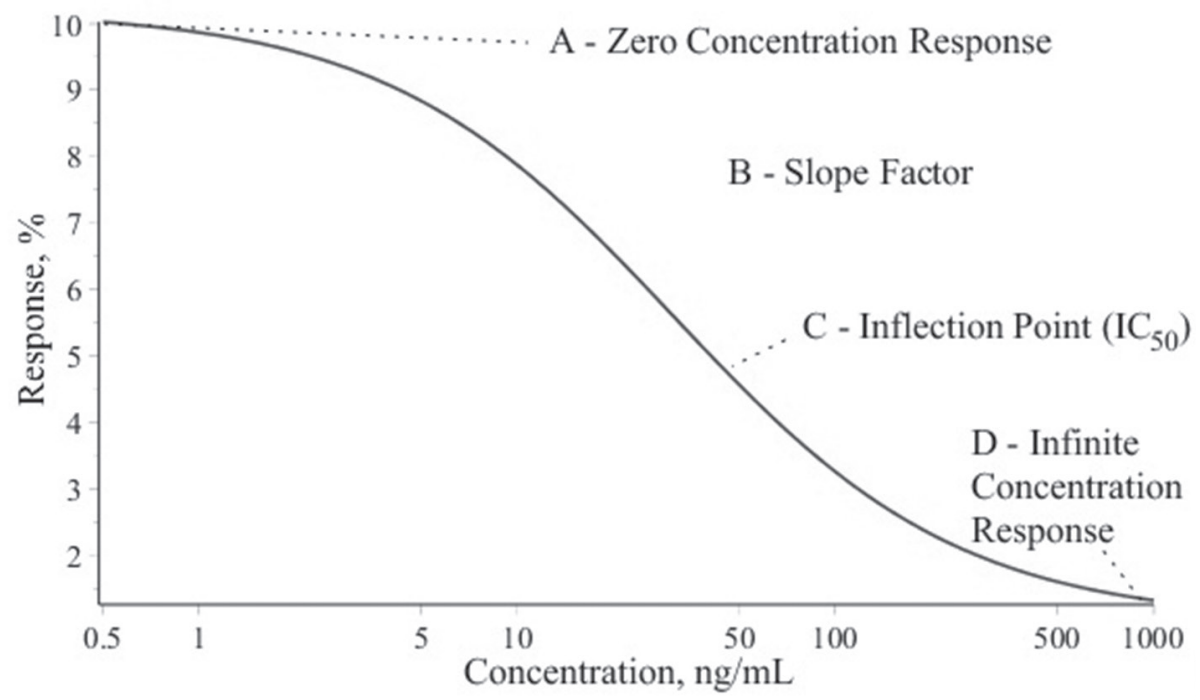

Fig. 1. Hill’s logistic curve with 4 parameters

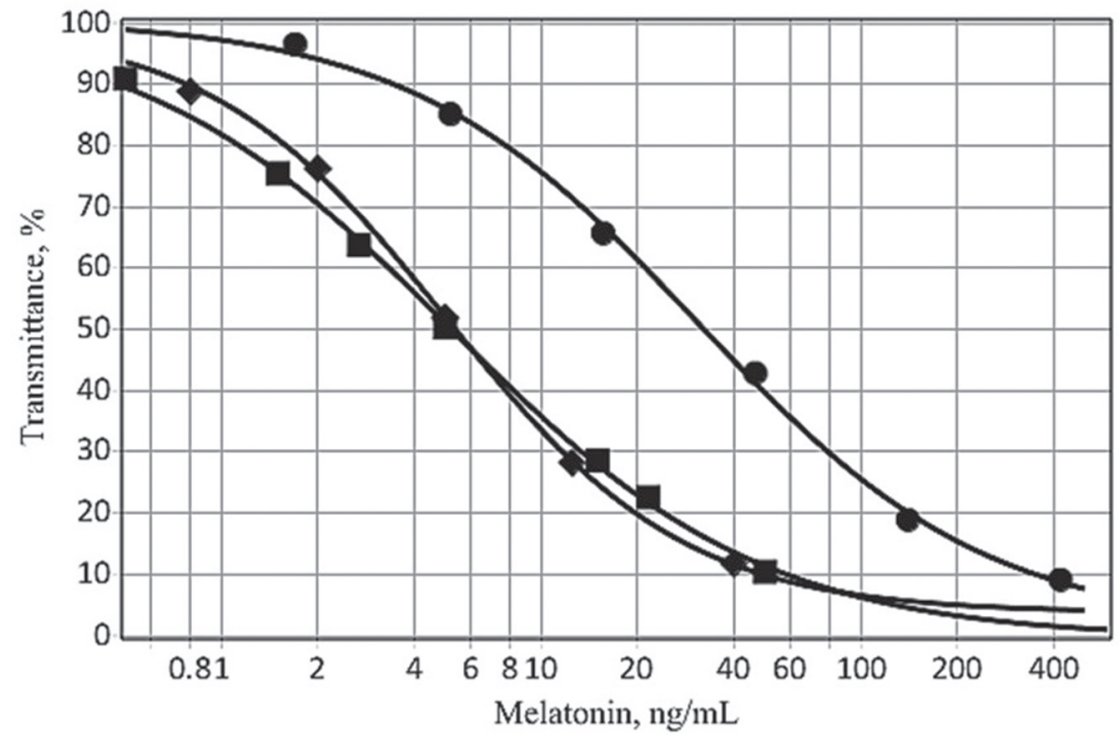

Fig. 2. The response-dosage curves: circles show the calibers of $[2,7,8]$ the diamonds present data $[9]$ and the boxes data [6]

Equation (1) describes ascending or descending logistic curve depending on sign of Hill's slope. We expected the descending type and so probably $\mathrm{d}<0$ [3].

There are different ways of determination of Hill's parameters [1, 3]. We used the computing technique [3] as the program package Statistics of Maple 17. That allowed us to fit of above Hill's parameters to experimental data of different producers.

Results and discussion. There are only three different calibrators: one of them has been described in $[2,3,7,8]$, two others in [6, 9]. Calibrator of [6] tested by RIA, others - by ELISA [2, 7-9].

The Fig. 2 presents three dosage-response curves where the response means the optical transmittance of analyte solution (B/B0). All logistic curves are descending (that is $\mathrm{d}<0$ ).

Both, Fig. 2 and Table 1, show the significant divergence between data $[2,7,8]$ and data $[6,9]$. The third coefficient c (alias EC50, ED50, LD50, IC50) causes mainly this large difference. Its value varies from 5.1 to 30.9 (about six times). Obviously, the difference of ELISA and RIA methods of dose measuring is «too much». The reasons of such mismatch are still unexplained. Note that the results of RIA and ELISA demonstrated first-rate accordance if we dealt with data of one laboratory [6, 9].

The rest three coefficients of Table 1 are in more or less agreement and have reasonable values. The first 
Hill's parameters

\begin{tabular}{|c|c|c|c|c|c|}
\hline Method & a & b & c & d & Data source \\
\hline ELISA & 1.3 & 100.7 & 30.9 & -0.96 & {$[2,7,8]$} \\
\hline ELISA & 3.7 & 99.7 & 5.1 & -1.17 & {$[9]$} \\
\hline RIA & -0.5 & 100.7 & 5.2 & -0.89 & {$[6]$} \\
\hline
\end{tabular}

of them was close to zero, the second one was near to 100 and the third coefficient was negative. Obtained results were expected.

Conclusions. There is the evident mismatch among calibrators of $[2,7,8]$ and those of $[6,9]$. The main Hill's parameter c that denoted also as EC50, ED50, LD50, IC50 is responsible for this variance, and the difference looks unexplainably large.

The set of calibers as well as the method of calibrating (i. e. ELISA) are the same despite on different sources $[2,7,8]$. Opposite, the methods (ELISA and RIA) and sets of calibers were different as for competing results of $[6,9]$ though both are from the same laboratory. These two methodically independent results of one laboratory are in good agreement.

Therefore, the titling question of this paper is still open because photometry of the human urine may give very different results as for Melatonin-sulfate dose nowadays. In the same time, the results of measurements should not depend on the calibrating set that would be in use. Thus, the reliable calibrators of urinary Melatonin-Sulfate are still wanted.

Acknowledgements. The authors wish to thank to Markiyan A. Hirnyk, PhD., Associated Professor of the Department of Higher Mathematics, Mathematical Economics and Statistics of Lviv University of Trade and Economics for presenting license version of the computer mathematics system Maple 18.

\section{References.}

1. Gadagkar, S. R., Call, G. B. (2015). Computational tools for fitting the Hill equation to dose-response curves. Journal of Pharmacological and Toxicological methods, 71, 68-76, doi:10.1016/j.vascn.2014.08.006.

2. IBL Melatonin Sulfate ELISA. (2014). Report of IBL International GMBH, Flughafenstrasse 52a, D-22335 Hamburg, Germany. Retrieved from http://www.iblinternational.com/media/catalog/product/R/E/RE54031_ IFU_en_Melatonin_Sulfate_ELISA_2014-05_sym3.pdf.
3. Khan, A. (2015). Calibrating response curves for the concentration of melatonin sulfate in human urine. Maplesoft. Retrieved from http://www.maplesoft.com/view. aspx?SF=153783/Melatonin\%200D\%20Response\%20 Curve.pdf

4. de Almeida, E. A., Di Mascio, P., Tatsuo, H., Moscovitch, A., Hardeland, R., Cardinali, D. P., Brown, G. M., PandiPerumal, S. R. (2011). Measurement of melatonin in body fluids: standards, protocols, and procedures. Child's Nervous System, 27(6), 879-891. Retrieved from http:// bibliotecadigital.uca.edu.ar/repositorio/investigacion/ measurement-melatonin-body-fluids-standards.pdf

5. Kunz, D., Mahlberg, R., Muller, C., Tilmann, A., Bes, F. (2004). Melatonin in patients with reduced REM sleep duration: two randomized controlled trials. The Journal of Clinical Endocrinology and Metabolism, 89(1), 128-134. doi:10.1210/jc.2002-021057.

6. Melatonin RIA. (2012). Report of Bühlmann Laboratories AG, Baselstrasse 55, CH-4124 Schönbuch, Switzerland. Revised 20 Nov. 2012. Retrieved from http://www. buhlmannlabs.ch/files/documents/core/Chronobiology/ifu/ rk-mel_ifu-ce-121120.pdf

7. Melatonin-Sulfate (EIA-1432) (2011). Report of DRG International Inc., USA. Revised 12 Sept. 2011 rm (Vers. 8.1). Retrieved from http://www.drg-international.com/ifu/ eia-1432.pdf (08.30.2015).

8. Melatonin Sulfate ELISA. Report of GenWay Biotech, Inc., 6777, Nancy Ridge Drive, San Diego, CA 92121, USA. Retrieved from http://www.genwaybio.com/media/custom/ upload/File-1313509984.pdf

9. 6-Sulfatoxymelatonin ELISA. (2011). Report of Bühlmann Laboratories AG, Baselstrasse 55, CH-4124 Schönbuch, Switzerland. Offered in the US by ALPCO26G Keewaydin Drive, Salem, NH 03079. Revised 16 May 2011, RUO-US. Retrieved from ttps://www.alpco.com/ pdfs/01/01-EK-M6S.pdf.

\section{Література.}

1. Gadagkar S. R. Computational tools for fitting the Hill equation to dose-response curves / S. R. Gadagkar, G. B. Call // Journal of Pharmacological and Toxicological Methods. — 2015. — Vol. 71. — P. 68-76. 
2. IBL Melatonin Sulfate ELISA : report [Electronic resource] / IBL International GMBH, Flughafenstrasse 52a, D-22335 Hamburg, Germany. - Retrieved from http:// www.ibl-international.com/media/catalog/product/R/E/ RE54031_IFU_en_Melatonin_Sulfate_ELISA_2014-05_ sym3.pdf (08.31.2015).

3. Khan A. Calibrating response curves for the concentration of melatonin sulfate in human urine [Electronic resource] / A. Khan. - 2015. — Maplesoft. — Retrieved from http:// www.maplesoft.com/view.aspx?SF=153783/Melatonin\%20 OD\%20Response\%20Curve.pdf.

4. Measurement of melatonin in body fluids: standards, protocols, and procedures / de E. A. Almeida, P. Di Mascio, H. Tatsuo [et al.] // Child's Nervous System. — 2011. Vol. 27, No 6. - P. 879-891.

5. Melatonin in patients with reduced REM sleep duration: two randomized controlled trials / D. Kunz, R. Mahlberg, C. Muller [et al.] // The Journal of Clinical Endocrinology and Metabolism. — Vol. 89, No 1. - 2004. — P. 128-134. 6. Melatonin RIA : report [Electronic resource] / Bühlmann Laboratories AG, Baselstrasse 55, CH-4124 Schönbuch,
Switzerland. - Revised 20 Nov. 2012. - Retrieved from http://www.buhlmannlabs.ch/files/documents/core/ Chronobiology/ifu/rk-mel_ifu-ce-121120.pdf (08.31.2015). 7. Melatonin-Sulfate (EIA-1432) : report [Electronic resource] / DRG International Inc., USA. - Revised 12 Sept. $2011 \mathrm{rm}$ (Vers. 8.1). — Retrieved from http:// www.drg-international.com/ifu/eia-1432.pdf (08.30.2015). 8. Melatonin Sulfate ELISA : report [Electronic resource] / GenWay Biotech, Inc., 6777, Nancy Ridge Drive, San Diego, CA 92121, USA. - Retrieved from http://www. genwaybio.com/media/custom/upload/File-1313509984. pdf (08.31.2015).

9. 6-Sulfatoxymelatonin ELISA : report [Electronic resource] / Bühlmann Laboratories AG, Baselstrasse 55, CH-4124 Schönbuch, Switzerland. - Offered in the US by ALPCO-26G Keewaydin Drive, Salem, NH 03079. — Revised 16 May 2011, RUO-US. — Retrieved from ttps:// www.alpco.com/pdfs/01/01-EK-M6S.pdf (08.30.2015). 